\title{
INTUISI SISWA MADRASAH IBTIDAIYAH (MI) DALAM PEMECAHAN MASALAH MATEMATIKA DIVERGEN
}

\author{
Zainal Abidin \\ Dosen Tetap Jurusan Pendidikan Matematika (TMA) \\ Fakultas Tarbiyah IAIN Ar-Raniry Banda Aceh
}

\begin{abstract}
Intuition is an immediate cognition received directly (self evident), without a reasoning process in depth, without requiring a jastifikasi or mathematical proof. Intuition plays a role in understanding the mathematical statements. However, intuition is also very involved in solving mathematical problems. Philosopher and educational experts regard intuition as a mental strategy or method that allows one stating the essence / essence of a phenomenon. The purposed of this study were (1) describe the intuition of students in mathematical problem solving divergent. From the results of this study can be summarized as follows: a) in understanding the problem, the kind of intuition that can be used for students classified in this type of intuition affirmatory. b) in planning the solution, intuition is used for students is to try to use division and multiplication. Jenis intuition is classified in this type of anticipatory intuition c) in implementing the solution, intuition is used is by way of trial and error, students tried to halve the amount of money available, and then used to buy a mango half and half to buy guava. Students also use a way of trying to multiply the number of mangoes that will be purchased at the price of one mango fruit and the remainder is used to buy guava and vice versa. Thus the kind of intuition that is used in this type of student is classified as anticipatory intuition d) Looking Back, intuition is used is to add the price of one mango and guava fruit multiplied by the number of mango and guava are purchased. With this type of intuition is used for students classified in this type of intuition affirmatory.
\end{abstract}

Keywords: Intuition, Pemecahan Masalah, Divergen 
Zainal Abidin - Intuisi Siswa MI Dalam Pemecahan Masalah Matematika

\section{A. Pendahuluan}

Intuisi adalah istilah tentang kemampuan memahami sesuatu tanpa melalui penalaran rasional dan intelektualitas yang tinggi. Sepertinya pemahaman itu tiba-tiba saja datang dari dunia lain dan diluar kesadaran. Menurut Poerwodarminto (1985), intuisi adalah daya atau kemampuan mengetahui atau memahami sesuatu tanpa dipikirkan secara mendalam atau dipelajari. Intuisi Juga merupakan wawasan atau pengetahuan yang menerangkan atau meramalkan peristiwa tanpa bergantung pada suatu proses penalaran secara sadar tanpa atau dengan buktibukti.

Konsep intuisi dijelaskan oleh Fischbein (1987) sebagai kognisi yang self evident, dapat diterima langsung, holistik, bersifat memaksa dan ekstrapolatif. Kognisi intuitif berbeda dengan kognisi secara analitik. Contoh, kebenaran pernyataan bahwa jumlah sudut-sudut dalam suatu segitiga adalah $180^{\circ}$ diyakini karena telah membuktikannya. Tetapi kebenaran pernyataan jarak terpendek antara dua titik adalah garis lurus tanpa harus membuktikannya baik secara formal ataupun secara empirik dan dari pengalaman siswa menyelesaikan bentuk perkalian $3 \times 3=9=3^{2}, 3 \times 3^{2}=3^{3}, \quad 3^{2} \times 3^{3}=3^{5}$ maka diperoleh bahwa $3^{a} \times 3^{b}=3^{a+b}$. Kebenaran pernyataan tersebut diperoleh tanpa melalui suatu pembuktian, namun diperoleh berdasarkan pengalaman semata. Penjelasan kebenaran suatu pernyataan karena harus membuktikan merupakan kognisi yang bersifat nonintuitif, tetapi kebenaran yang munculnya secara siswatif dan diterima secara langsung (tanpa pembuktian secara formal) merupakan kognisi secara intuitif.

Konsep intuisi yang diuraikan oleh Fischbein tersebut menjelaskan bahwa intuisi berperan dalam memahami pernyataanpernyataan matematika. Namun demikian intuisi juga sangat berperan dalam pemecahan masalah matematika. Sebagai contoh, untuk membuktikan kebenaran pernyataan matematika biasanya pada saat awal akan berpikir secara sepintas dan global cara pembuktian yang digunakan, apakah bukti langsung atau tidak langsung. Berpikir secara sepintas dan global tersebut merupakan salah satu ciri/karakteristik intusi yang digunakan dalam menyelesaikan masalah matematika. 
Zainal Abidin - Intuisi Siswa MI Dalam Pemecahan Masalah Matematika

Penggunaan intuisi dalam matematika bisa saja dapat mengakibatkan kesalahan dalam pemahaman konsep, namun demikian banyak hasil penelitian yang mendukung pentingnya intuisi dalam pembelajaran matematika dan potensinya dalam meningkatkan pemahaman terhadap matematika serta dalam pemecahan masalah matematika. Pentingnya intuisi dalam pembelajaran matematika seperti yang diungkapkan oleh Raman (2002). Raman menginvestigasikan cara pemecahan masalah kalkulus terhadap mahasiswa, asisten dosen, dan profesor. la menemukan bahwa representasi dan interpretasi intuitif dapat memandu individu membuat klaim matematika yang benar. Selain itu ditemukan bahwa bila individu menemukan ide kunci (key idea) dalam suatu pembuktian, maka ia dapat mengaitkan pemahaman terhadap klaim dalam pembuktian dengan bukti formal pernyataan matematika. Selain Raman, Ramos dan Tall (2005) dalam suatu studi kasus berbasis wawancara meminta mahasiswa untuk membuktikan suatu pernyataan matematika, "Turunan fungsi genap yang differensiabel adalah fungsi ganjil " Salah seorang mahasiswa memberikan respon sebagai berikut. Pertama, mahasiswa tersebut merespon dengan melakukan eksperimen terhadap fungsi $f$ sederhana dengan merepresentasikan garis singgung grafik fungsi. Ia dapat menunjukkan bahwa garis singgung-garis singgung grafik pada pasangan titik yang berjarak sama terhadap sumbu koordinat dari grafik fungsi-fungsi tersebut, saling berlawanan, yaitu $f(-x)=-f(x)$. Ide-ide ini memberinya pemahaman bahwa pernyataan tersebut benar. Bagian ini merupakan tahap untuk meyakinkan dirinya akan kebenaran suatu pernyataan, namun demikian gagasan ini dianggapnya belum dapat meyakinkan orang lain akan kebenaran pernyataan tersebut. Ia kemudian mencoba membangun gagasan ketika menyadari sifat fungsi genap yang simetri terhadap sumbu tegak sistem koordinat, yaitu $f(x)=f(-x)$. Dengan mengambil turunan fungsi pada kedua sisi, akhirnya ia dapat membuktikan pernyataan matematika tersebut. Dari sini terlihat bahwa peranan intuisi dalam menemukan jawaban sangat penting, yaitu dalam mengambil turunan fungsi pada kedua sisi. Secara intuitif dia mengambil turunan fungsi pada kedua sisi.

Pemecahan masalah merupakan tujuan yang akan dicapai dengan jalan mengadakan pengamatan yang teliti dan reorganisasi terhadap unsur-unsur dari totalitas masalah tersebut sehingga lahirlah suatu pemahaman yang utuh. Menurut Suharnan (2005: 6) pemecahan masalah 


\section{Zainal Abidin - Intuisi Siswa MI Dalam Pemecahan Masalah Matematika}

adalah proses mencari dan menemukan jalan keluar terhadap suatu masalah atau kesulitan. Pemecahan masalah memerlukan suatu pengetahuan dasar yang tersimpan dalam pikiran disinergikan dengan informasi dalam bentuk masalah dan terjadilah proses asimilasi dan akomodasi kemudian dikonstruk melalui suatu proses berpikir sehingga terbentuk struktur pengetahuan dalam bentuk jawaban atau gagasan.

Masalah matematika divergen merupakan suatu istilah yang digunakan peneliti berdasarkan pada pemahaman masalah matematika yang bersifat terbuka (open-ended). Menurut Guilford (dalam Munandar, 1991) bahwa berpikir divergen adalah bentuk pemikiran terbuka, yang menjajaki macam-macam kemungkinan jawaban terhadap permasalahan atau masalah.

Pemecahan masalah matematika divergen akan lebih banyak memberikan pengalaman-pengalaman berpikir tingkat tinggi dan dengan sendirinya akan terbentuk pola berpikir yang sistematis, efektif, dan efisien. Csikszenmihalyi (dalam Williams, 2002) menjelaskan bahwa kekontinuan dalam menyelesaikan tantangan intelektual yang kompleks dengan menggunakan gagasan matematika akan semakin meningkatkan kemampuan berpikir tingkat tinggi.

\section{B. Metode Penelitian}

Penelitian ini ingin mengungkapkan intuisi siswa dalam pemecahan masalah matematika divergen. Lebih jauh akan diungkapkan intuisi siswa dalam pemecahan masalah matematika divergen yaitu dalam (1) memahami masalah, (2) membuat rencana pemecahan, (3) melaksanakan rencana, dan (4) melihat kembali. Jadi penelitian ini termasuk jenis penelitian eksploratif dengan pendekatan kualitatif dengan data utamanya berupa kata-kata yang dirangkaikan menjadi kalimat. Pendekatan kualitatif dipilih karena ingin mengungkapkan intuisi siswa dalam pemecahan masalah matematika divergen. Analisis dilakukan secara mendalam pada intuisi siswa dalam pemecahan masalah matematika divergen. Mengungkapkan intuisi siswa dilakukan dengan merekam semua aktifitas dan suara siswa pada saat menyelesaikan masalah matematika divergen yang diberikan dan juga melakukan wawancara mendalam. 


\section{Zainal Abidin - Intuisi Siswa MI Dalam Pemecahan Masalah Matematika}

Penelitian ini dilaksanakan pada MIN Banda Aceh kelas enam. Penelitian ini tergolong dalam penelitian eksploratif dengan pendekatan kualitatif, maka peneliti pada penelitian ini berperan sebagai instrumen utama dalam mengumpulkan data, yang dibantu dengan instrumen pendukung seperti instrumen lembar tugas pemecahan masalah matematika divergen, dan alat perekam berupa handycam. Instrumen berikutnya adalah lembar tugas berupa soal atau masalah matematika divergen yang harus dikerjakan atau dipecahkan oleh siswa. Sebelum soal tersebut digunakan, terlebih dahulu divalidasi oleh ahli pendidikan matematika dan guru matematika. Validasi diarahkan pada kesesuaian masalah matematika divergen dengan tujuan penelitian, konstruksi masalah matematika divergen dan kesesuaian bahasa yang digunakan, sehingga intuisi siswa bisa muncul melalui pemecahan masalah divergen tersebut.

Penelitian ini mengkaji tentang intuisi siswa dalam pemecahan masalah matematika divergen. Pengumpulan data dilakukan dengan memberikan masalah matematika divergen kepada siswa untuk diselesaikan. Dalam proses pemecahan masalah matematika divergen siswa mengungkapkan dengan suara keras apa yang sedang dipikirkan. Peneliti merekam ungkapan verbal siswa dan mencatat perilaku (ekspresi) siswa, termasuk hal-hal unik yang dilakukan siswa, ketika menyelesaikan masalah tersebut.

Proses analisis data dalam penelitian ini dilakukan dengan langkah-langkah: (1) mentranskrip data verbal yang telah terkumpul, (2) menelaah seluruh data yang tersedia dari berbagai sumber, yaitu dari wawancara mendalam, pengamatan yang telah dituliskan dalam catatan lapangan, dan hasil kerja siswa berupa pemecahan masalah matematika divergen; (3) mengadakan reduksi data dengan membuat abstraksi. Abstraksi merupakan usaha membuat rangkuman yang inti, proses, dan pernyataan-pernyataan yang perlu dijaga untuk tetap berada di dalamnya; (4) menyusun dalam satuan-satuan yang selanjutnya dikategorisasikan dengan membuat pengkodean; (5) menggambarkan struktur intuisi siswa dalam menyelesaikan masalah matematika divergen; (6) menganalisa intuisi siswa; (7) menganalisa hal-hal yang menarik; dan (8) menarik kesimpulan. 
Zainal Abidin - Intuisi Siswa MI Dalam Pemecahan Masalah Matematika

\section{Hasil Penelitian dan Pembahasan}

\section{Intuisi Siswa dalam Memahami Masalah}

Siswa dapat dengan mudah memahami masalah, ini terlihat bahwa siswa dapat dengan mudah menceritakan apa yang diketahui dan apa yang ditanya pada masalah dan juga siswa dapat dengan mudah menuliskannya.

Dari hasil wawancara diperoleh bahwa siswa dapat dengan mudah memahami masalah dan dapat dengan mudah pula menuliskan apa yang diketahui dan apa yang ditanyakan pada masalah. Hal ini sesuai dengan yang dikatakan oleh Hah Roh (2005) bahwa pemahaman intuitif sebagai kognisi segera suatu konsep tanpa bukti secara ketat (rigorous proof). Dalam memahami masalah siswa sangat kokoh pada pendiriannya tentang yang diketahui dan yang ditanyakan pada soal seperti yang telah dikatakan dan dituliskan sebelumnya. Siswa dengan tegas mengatakan bahwa hanya itu yang diketahui pada soal. Hal itu mengindikasikan bahwa siswa menggunakan intuisi dalam memahami masalah tersebut. Siswa secara langsung dan lancar menyebutkan apa yang diketahui dan apa yang ditanyakan pada soal/masalah yang diberikan dan siswa telah memenuhi kriteria menggunakan intuisi dalam memahami masalah tersebut. Menurut Ilham Miggi (2011:57) intuisi merupakan kognisi atau proses mental dalam memahami sesuatu, atau dalam mengkonstruksi pengetahuan. Proses mental ini bersifat langsung, segera, dan tidak membutuhkan pembenaran atau jastifikasi. Berdasarkan hal tesebut, maka dapat disimpulan bahwa dalam memahami masalah, jenis intuisi yang digunakan siswa tergolong dalam jenis intuisi affirmatory, yaitu intuisi yang digunakan untuk menegaskan pernyataan, interpretasi atau representasi yang digunakan dalam memahami masalah matematika divergen yang diberikan yang secara individual dapat diterima secara langsung, self evident, global dan cukup secara instrinsik.

\section{Intuisi Siswa dalam Merencanakan Pemecahan Masalah}

Dalam merencanakan pemecahan siswa menggunakan cara mencoba-coba, yaitu dengan cara membagi 4000 dengan dua, setengahnya untuk beli mangga dan setengahnya yang lain untuk membeli jambu. 
Dari hasil wawancara diperoleh bahwa siswa menyelesaikan masalah dengan cara membagi dua uang yang ada yaitu 4000 dibagi 2, setengahnya untuk membeli jambu dan setengah lagi mangga. Siswa dalam menyelesaikan masalah ini menggunakan cara coba-coba dan kemudian membagi. Jadi intuisi yang digunakan siswa dalam merencanakan pemecahan masalah adalah dengan cara coba-coba dan lalu membagi. Cara yang diterangkan oleh siswa tersebut dikemukakan oleh siswa secara tiba-tiba dan lancar serta spontan setelah memikirkan beberapa saat. Cara pemecahan tersebut bukan berasal dari penggunaan definisi, teorema, maupun rumus matematika, dan juga cara tersebut tidak sama dengan cara yang terdapat dalam bubu-buku teks matematika dan juga tidak sama seperti yang sering dibahas dalam pembelajaran di kelas. Perencanakan pemecahan masalah yang dikemukakan oleh siswa secara intuitif dianggab benar dengan sendirinya dan dapat digunakan untuk menyelesaikan masalah. Hal ini sejalan dengan Piaget (dalam Tall, 1992) memandang intuisi sebagai kognisi yang diterima langsung tanpa perlu untuk menjastifikasi atau menginterpretasi secara eksplisit

Pernyataan-pernyataan yang telah dikemukakan siswa tersebut merupakan pernyataan secara intuitif dan bukan berdasarkan rumus atau definisi matematika dan belum dibuktikan secara formal. Fischbein (1994) mendefinisikan intuisi sebagai immediate knowledengane (kognisi segera) yang disetujui secara langsung tanpa pembenaran. Pernyataan siswa tersebut tidak didasarkan pada definisi atau teorema dan rumus-rumus matematika. Namun hanya berdasarkan pemikiran secara intuitif, dan pernyataan itu dianggab benar dengan sendirinya.

Cara yang dikatakan oleh Siswa di atas tidak diketahui dari mana munculnya dan siswa juga mengatakan bahwa hanya itu cara atau rencana pemecahan masalah yang mampu diberikan. Siswa juga mengatakan bahwa benar atau salah rencana yang dibuatnya adalah setelah dicek atau diperiksa kebenarannya.

Siswa dalam merencanakan pemecahan masalah tersebut dapat dikatakan bahwa pemecahan tersebut merupakan pemecahan yang berdasarkan intuisi. Ini menunjukkan bahwa siswa benar telah menggunakan intuisi dalam merencanakan pemecahan masalah, dengan demikian dapat disimpulan bahwa dalam merencanakan pemecahan masalah, jenis intuisi yang digunakan siswa tergolong dalam jenis intuisi anticipatory. Fischbein (1982, 1983, 1999) menyatakan bahwa terdapat 


\section{Zainal Abidin - Intuisi Siswa MI Dalam Pemecahan Masalah Matematika}

intuisi yang digunakan orang dalam aktivitas pemecahan masalah, yaitu intuisi anticipatory dan intuisi conlusive. Intuisi anticipatory merupakan aktivitas mental yang berlangsung ketika siswa berusaha untuk merencanakan pemecahan masalah dalam rangka untuk menyelesaikan masalah dan rencana atau langkah pemecahan tersebut tidak secara langsung dapat diperoleh, melainkan setelah berpikir beberapa saat, namun demikian rencana tersebut muncul secara spontan. Rencana pemecahan yang diberikan oleh Siswa tersebut merupakan rencana pemecahan yang sangat global, berupa dugaan, atau klaim awal dalam sebuah rencana pemecahan masalah, rencana atau cara tersebut belum tentu benar dan tidak didasarkan pada bukti formal atau bukti analitik dalam merencanakan pemecahan masalah tersebut.

\section{Intuisi Siswa dalam Melaksanakan Memecahan Masalah}

Dalam melaksanakan rencana siswa mencoba membagi 4000 dengan 2, kemudian hasilnya digunakan untuk membeli jambu dan mangga. Namun secara tiba-tiba siswa mencoba dengan cara lain yaitu siswa mencoba dengan cara mengalikan harga satu mangga dengan 6 dan harga satu jambu dengan 9, namun siswa merasa bingung dengan hasil yang didapatkan yaitu sudah melebihi dari uang yang tersedia yaitu 4000 .

Dari petikan hasil wawancara diperoleh bahwa siswa melakukan dengan cara mencoba mengalikan banyaknya mangga yang akan dibeli dengan harga satu buah mangga dan banyaknya jambu yang akan dibeli dikalikan dengan harga satu buah jambu. Untuk menemukan banyak mangga dan jambu yang lain siswa mengalikannya dengan suatu bilangan bulat tertentu yang bila dijumlahkan akan menjadi 4000. Intuisi yang digunakan siswa dalam melaksanakan rencana pemecahan masalah yang diberikan adalah dengan cara coba-coba, membagi dan mengalikan.

Cara tersebut merupakan pandangan yang global, berupa dugaan, atau klaim awal, dalam sebuah pemecahan masalah, dan tanpa bukti formal atau bukti analitik. Fischbein (1994) mendefinisikan intuisi sebagai immediate knowledengane (kognisi segera) yang disetujui secara langsung tanpa pembenaran. Cara yang dikerjakan siswa tersebut merupakan cara yang merupakan pandangan yang global, berupa dugaan, atau klaim awal, dalam sebuah pemecahan masalah, dan tanpa bukti formal atau bukti analitik. Menurut Poincare (dalam Fischbein, 1987), generalisasi yang dibangun secara induktif adalah salah satu kategori dasar intuisi.

54 Madrasah, Vol. 4 No. 1 Juli-Desember 2011 
Siswa hanya mengetahui cara mengerjakan atau memecahkan masalah seperti yang telah dikemukakan di atas, dan cara tersebut tidak diketahui berasal dari mana atau ide darimana, siswa hanya mencoba-coba saja. Cara yang telah dilaksanakan tersebut merupakan pandangan yang global, berupa dugaan, atau klaim awal dalam sebuah pemecahan masalah, dan tanpa bukti formal atau bukti analitik. Cara tesebut bukan berdasarkan definisi, teorema atau rumus matematika, dan juga tidak didasari dari penggunaan prosedur, formula atau strategi standar seperti yang ada dalam buku-buku teks matematika dan juga tidak seperti yang biasanya dibahas atau dipelajari dalam pembelajaran di kelas atau sekolah. Ini sesuai dengan Piaget (dalam Tall, 1992), dia memandang intuisi sebagai kognisi yang diterima langsung tanpa perlu untuk menjastifikasi atau menginterpretasi secara eksplisit.

Berdasarkan analisis data yang telah diuraikan di atas terlihat siswa menyatakan dan mengerjakan secara langsung dan lancar rencana pemecahan masalah setelah memikirkan beberapa saat. Cara atau pelaksanaan pemecahan yang dilakukan oleh siswa tersebut dapat dikatakan berdasarkan intuisi. Ini menunjukkan bahwa siswa benar telah menggunakan intuisi dalam melaksanakan rencana pemecahan masalah dan dengan demikian dapat disimpulan bahwa dalam melaksanakan rencana pemecahan masalah, jenis intuisi yang digunakan siswa tergolong dalam jenis intuisi anticipatory. Fischbein (1982, 1983, 1999) menyatakan bahwa terdapat intuisi yang digunakan orang dalam aktivitas pemecahan masalah, yaitu intuisi anticipatory dan intuisi conlusive. Intuisi anticipatory merupakan aktivitas mental yang berlangsung ketika siswa berusaha untuk melaksanakan rencana pemecahan masalah dalam rangka untuk menyelesaikan masalah dan pemecahan atau langkah pemecahan tersebut tidak secara langsung dapat diperoleh, melainkan setelah berpikir beberapa saat, namun demikian pelaksanaan rencana pemecahan tersebut muncul secara spontan. Pemecahan yang telah dikerjakan oleh siswa tersebut merupakan pemecahan yang bersifat global, berupa dugaan, klaim awal, dalam melaksanakan rencana pemecahan masalah, pemecahan yang telah dilakukan siswa tersebut tidak didasarkan pada bukti formal atau bukti analitik dalam sebuah pemecahan masalah.

\section{Intuisi siswa dalam Melihat Kembali Hasil Pemecahan Masalah}

Untuk melihat kembali pemecahan masalah yang telah dikerjakan, siswa melakukan dengan cara menambahkan semua harga mangga dan 


\section{Zainal Abidin - Intuisi Siswa MI Dalam Pemecahan Masalah Matematika}

jambu yang dibeli kemudian dikalikan dengan banyaknya mangga dan jambu. Cara yang dilakukan siswa dalam melihat kembali pemecahan terlihat seperti cara untuk menggeneralisasi bahwa menambahkan semuanya merupakan cara yang tepat. Hal ini sejalan dengan Poincare (dalam Fischbein, 1987), mengatakan bahwa generalisasi yang dibangun secara induktif adalah salah satu kategori dasar intuisi. Dari hasil wawancara terlihat bahwa siswa melaksanakan secara langsung dan lancar dalam melihat kembali pemecahan masalah dan siswa dapat dikatakan bahwa benar yang dikerjakannya dalam melihat kembali pemecahan masalah berdasarkan intuisi. Ini menunjukkan bahwa siswa benar-benar menggunakan intuisi dalam melihat kembali pemecahan masalah yang diberikan. Jenis intuisi yang digunakan siswa ini tergolong dalam jenis intuisi affirmatory, yaitu intuisi yang digunakan untuk menegaskan pernyataan, interpretasi atau representasi yang digunakan dalam melihat kembali pemecahan masalah matematika divergen yang diberikan yang secara individual dapat diterima secara langsung, self evident, global dan cukup secara instrinsik.

\section{Penutup}

\section{Kesimpulan}

1) Intuisi Siswa dalam Memahami Masalah

Berdasarkan pembahasan yang telah diuraikan di atas, maka dapat disimpulan bahwa dalam memahami masalah matematika divergen, jenis intuisi yang digunakan siswa tergolong dalam jenis intuisi affirmatory, yaitu intuisi yang digunakan untuk menegaskan pernyataan, interpretasi atau representasi yang digunakan dalam memahami masalah matematika divergen yang diberikan yang secara individual dapat diterima secara langsung, self evident, global dan cukup secara instrinsik.

2) Intuisi Siswa dalam Merencanakan Pemecahan Masalah

Berdasar pembahasan di atas dapat disimpulan bahwa dalam merencanakan pemecahan masalah matematika divergen, jenis intuisi yang digunakan siswa tergolong dalam jenis intuisi anticipatory. Intuisi anticipatory merupakan aktivitas mental yang berlangsung ketika siswa berusaha untuk merencanakan pemecahan masalah dalam rangka untuk menyelesaikan masalah dan rencana atau langkah pemecahan tersebut tidak secara langsung dapat diperoleh, melainkan setelah berpikir beberapa saat, namun demikian rencana tersebut muncul secara spontan. 


\section{Zainal Abidin - Intuisi Siswa MI Dalam Pemecahan Masalah Matematika}

\section{3) Intuisi Siswa dalam Melaksanakan Pemecahan Masalah}

Intuisi yang digunakan siswa dalam melaksanakan pemecahan adalah dengan cara mencoba-coba, siswa mencoba membagi dua banyaknya uang yang tersedia, lalu setengahnya digunakan untuk membeli Mangga dan setengahnya lagi untuk membeli jambu. Siswa juga menggunakan cara mencoba mengalikan banyaknya mangga yang akan dibeli dengan harga satu buah mangga lalu sisanya digunakan untuk membeli jambu dan begitu sebaliknya. Maka dengan demikian, dapat disimpulkan bahwa jenis intuisi yang digunakan siswa dalam melaksanakan pemecahan masalah matematika divergen tergolong dalam jenis intuisi anticipatory.

4) Intuisi Siswa dalam Melihat Kembali Hasil Pemecahan Masalah

Intuisi yang digunakan oleh siswa dalam melihat kembali hasil yang telah didapatkan adalah dengan cara menambahkan semua hasil perkalian satu buah mangga dan satu buah jambu dengan banyaknya mangga dan jambu yang dibeli. Dengan demikian dapat disimpulkan bahwa jenis intuisi yang digunakan siswa dalam melihat kembali pemecahan masalah matematika divergen tergolong dalam jenis intuisi affirmatory, yaitu intuisi yang digunakan untuk menegaskan pernyataan, interpretasi atau representasi yang digunakan dalam melihat kembali pemecahan masalah matematika divergen yang diberikan yang secara individual dapat diterima secara langsung, self-evident, global dan cukup secara instrinsik.

\section{Saran-Saran}

1) Berdasarkan hasil penelitian ini diharapkan pada pengajar matematika khususnya guru matematika sekolah agar mempertimbangkan dan memperhatikan intuisi siswa dalam pengembangan model pembelajaran matematika sekolah.

2) Berdasarkan hasil penelitian ini diharapkan pada pengajar matematika khususnya guru matematika sekolah agar mempertimbangkan dan memperhatikan intuisi siswa dalam merencanakan dan melaksanakan pembelajaran matematika sekolah khususnya berkaitan dengan pemecahan masalah matematika divergen. 
Zainal Abidin - Intuisi Siswa MI Dalam Pemecahan Masalah Matematika

\section{E. Daftar Pustaka}

Calder dan Sarah, 2002. Using "think Alouds" to Evaluate Deep Understanding. http://www.brevard.edu/fyc/listserv/remarks/calderandcarlso n.htmm diakses 12 mei 2009.

Erricson dan Simon, 1996. Protocol Analysis: Verbal Reports as Data. MIT Press. New York.

Fischbein, E. (1987). Intuition in science and mathematics An educational approach, Reidel, The Netherlands.

Fischbein, E. 1994. The Interaction Between The Formal, The Algorithmic, and The intuitive Components in a Mathematical Activity. In R. Biehler, R. W. Scholz, R.

Fischbein, E. 1999. Intuition and Schemata in Mathematical Reasoning. Educational Studies In Mathematics Vol. 38: Netherland: Kluwer Academic Publishers

Ilham Miggi. (2011). Profil Intuisi Siswa dalam Memahami Konsep Limit Fungsi Berdasarkan Perbedaan Gender. Disertasi Tidak diterbitkan. Unesa. Surabaya.

Munandar. U. (1991). Kreativitas dan Keberbakatan. Penerbit PT Gramedia Pustaka Utama, Jakarta.

Olson, G.M., Duffy, S.A, and Mack, R.L, 1988. Think-Out-Loutds as a Method for Studying Real-Time Comprehension Processes. (pp.253-286). Hillsdole, New Jersey. Lawrence Erlbaum Associates, Publisher.

Poerwodarminto. 1985. Kamus Besar Bahasa Indonesia. Jakarta: Balai Pustaka

Ramos and Tall (2005). Personal and public aspects of formal proof a theory and a single-case study, in D. Hewitt and A. Noyes (Eds), Proceedings of the sixth British Congress of Mathematics Education held at the University of Warwick, pp. 97-104. Available from $\mathrm{N} \%$ «NN.bsrlm.org.uk,

Raman, M. (2002). Proof and Justification in Collegiate Calculus. Unpublished doctoral dissertation. University of California, Berkeley.

Tall, D. (1992). The transition to advanced mathematical thinking: functions, limits, infinity, and proof In D. A. Grouws (Ed.), Handbook of research on mathematics teaching and learning (pp. 495511).

58 Madrasah, Vol. 4 No. 1 Juli-Desember 2011 
Zainal Abidin - Intuisi Siswa MI Dalam Pemecahan Masalah Matematika

New York: Macmillan.

Williams G. (2002) Autonomous Acces, Spontaneous Pursuit, and Creative Execution: Insightful and Creative Mathematical Problem Solving. Makalah konferensi MAV. University of Melbourne.

Zeev, Star. (2002) Intuitive Mathematics: Theoretical and Educational implications, (tersedia dalam http://www.msLL edu/jonstar/papers/intuition.pdf.)

59 Madrasah, Vol. 4 No. 1 Juli-Desember 2011 